Global Journal of Human Resource Management

Vol.8, No.1, pp.1-19, February 2020

Published by ECRTD-UK

Print ISSN: 2053-5686(Print), Online ISSN: 2053-5694(Online)

\title{
PSYCHOLOGICAL DISTRESS OF AGUATA SUBURBAN FEMALE BANKERS, ANAMBRA STATE, NIGERIA: INTERPLAY OF PERCEIVED ORGANIZATIONAL JUSTICE, JOB-RELATED TENSION, AND ORGANIZATIONAL FRUSTRATION
}

\author{
Okechukwu Dominic Nwankwo, PhD \\ Department Of Psychology, Chukwuemeka Odumegwu Ojukwu University, Igbariam Campus, \\ P.M.B. 6059, Awka, Anambra State, Nigeria. \\ Correspondence author \\ Christian Nzubechukwu Ekebosi \\ Department Of Sociology, Chukwuemeka Odumegwu Ojukwu University, Igbariam Campus, \\ P.M.B. 6059, Awka, Anambra State, Nigeria. \\ Olofin Funke Temidayo, \\ Department Of Psychology, Baze University, Abuja, Nigeria. \\ Precious Rosemary Ike, \\ Department Of Psychology, Nnamdi Azikiwe University, P.M.B. 5025, Awka, \\ Anambra State, Nigeria. \\ Evelyn Chinwe Alobele \\ Department Of Psychology, Chukwuemeka Odumegwu Ojukwu University, Igbariam Campus, \\ P.M.B. 6059, Awka, Anambra State, Nigeria
}

\begin{abstract}
This study examined psychological distress of Aguata suburban female bankers, Anambra State, Nigeria, with the objectives of understanding the interplay of job-related tension, perceived organizational justice and organizational frustration, using 89 participants, age-ranged 26-56 years, mean age 39.19, and standard deviation 7.35, sampled through cluster sampling technique. Reliable/valid instruments used were Job-related Tension Scale, PerceivedOrganizational Justice Scale, and Organizational Frustration Scale. Multiple regression statistic tested the hypotheses postulated. The findings were job-related tension had significant positive correlation and significantly predicted 50\% with organizational frustration; as well as have negative correlation with perceived-organizational justice of the participants. Perceivedorganizational justice did not significantly predict organizational frustration (21\% only) of female bankers. Recommendations were: Psychological intervention mechanisms should be provided for bankers. Organizational justice policies need to be complimented with proaction facilitators to reduce psychological distress of female bankers.
\end{abstract}

KEYWORDS: psychological-distress, female-bankers, job-tension, organizational-justice, organizational-frustration, Nigeria 
Global Journal of Human Resource Management

Vol.8, No.1, pp.1-19, February 2020

Published by ECRTD-UK

Print ISSN: 2053-5686(Print), Online ISSN: 2053-5694(Online)

\section{INTRODUCTION}

Psychological distress is an unpleasant experience that interferes with coping ability, as well as hampers normal and healthy functioning (Pallipedia, 2020). Banking entails both social and economic systems of a society. The bank's health is often diagnosed from its financial statement (Mukah, 2020). But the psychological (human) health characteristics of banking are ignored. This has created a gap in knowledge, which this study seeks to explore. Interestingly, Mukah (2020) noted that treating bankers decently and fairly enhances performance. In Nigeria, banking has been observed to be fraught with myriad of challenges for female bankers, such as sexual harassment (Pina \& Gannon, 2010), work-family conflict (Fawole \& Isiaq, 2017), fear of workplace bullying by management or co-workers (Hussain \& Aslam, 2015), job insecurity (Kunle, Shittu, \& Kolawole, 2013), and gender discrimination (Iyiola, 2011). Psychological distress can be caused by people's perceptions of unfairness and their tendencies to think, feel, and act in radicalizing way (van den Bos, 2020). Socio-employment challenges may create psychological distress like job-related tension and organizational frustration among female bankers. These psychological distress may exist even when there is a moderating factor like organizational justice. This could be an indication of absence of empathy that bolsters others' well-being (Zaki, 2020) in the banks. Hence, the current study aimed at investing psychological distress of Aguata suburban female bankers, Anambra State, Nigeria. The interplay of job-related tension, perceived-organizational justice, and organizational frustration were explored in the study.

\section{Statement of the Problem}

Banking industry is very crucial to the life of any nation. Undoubtedly, the population of the feminine intelligentsia in Anambra State, Nigeria, is very enormous. The female gender is a partner with the male gender in social and human development. In Anambra State, Nigeria, even the entire Biafra (Eastern region of Nigeria), it is the characteristics of the female gender to outnumber the male gender in any occupation or industry that she develops interest in, which currently include the banking industry. The vulnerabilities of the feminine gender are indisputable, even with her enormous population, centrality, and inevitability in social and human endeavours, including banking industry. The vulnerabilities carry with it certain psychological distress like job-related burnout and organizational frustration. Female bankers with psychological distress exhibit what van den Bos (2020) called radicalizing attitude.

Previous studies have identified socio-employment challenges female bankers face in Nigeria to be sexual harassment (Pina \& Gannon, 2010), work stressors predisposing to work-family conflict (Fawole \& Isiaq, 2017), fear of possible workplace bullying by management or co-workers (Hussain \& Aslam, 2015), job insecurity (Kunle et al., 2013), gender discrimination (Iyiola, 2011), and responsibility of pursuing unattainable financial target within a stipulated time frame (Ogechukwu, 2013). Consequently, these socio-employment challenges have the potential of 
Global Journal of Human Resource Management

Vol.8, No.1, pp.1-19, February 2020

Published by ECRTD-UK

Print ISSN: 2053-5686(Print), Online ISSN: 2053-5694(Online)

engendering psychological distress like tension and frustration among female bankers, nonetheless the moderating influence of perceived-organizational justice. Dearth of knowledge and studies seemed to exist on psychological distress among bankers (and the female bankers seemed worse off), because focus and emphasis are always on the economic and social (sociological) parameters of the banking system. This has created a gap in knowledge, which this study seeks to fill through exploring the interplay of job-related tension, perceived-organizational justice, and organizational frustration of Aguata suburban female bankers, Anambra State, Nigeria.

\section{Purpose of the Study}

1. To find out incidence of psychological distress in the Nigerian banking socio-economy, since psychological distress breeds corruption.

2. To find out elements of psychological distress among female bankers in Nigeria, since it has been alluded by (Cheeseborough, Overstreet \& Ward, 2020) that psychosocial distress predisposes the female gender to sexual indecency.

3. To investigate whether justice has potency of resolving or at least has moderating influence on frustration and tension, van den Bos (2020) having observed that perceived injustice induces radicalization.

4. To explore further the employment changes of women in Nigeria as it concerns integrating work and family.

\section{Significance of the Study}

1. The study will be invaluable in providing knowledge-base for human resources management.

2. The study will be relevant in sanitizing the Nigerian banking socio-economy.

3. Knowledge from the study will enhance performance effectiveness, especially for the female gender that integrates work and family.

4. The finding will equally contribute in canvassing for a favourable psychological work environment for the female gender.

\section{Operational Definition of Terms}

Job-related tension: This is the pressure which affects psychological or physiological performance and forces a person to deviate from normal functioning, as measured with job-related tension scale by Kahn, Wolfe, Quinn, Snoek, and Rosenthal (1964).

Perceived-organizational justice: This is the reflection of employees' perception of fair treatment in the workplace, as measured with perceived-organizational justice questionnaire (POJQ) by Niehoff and Moorman (1993).

Organizational frustration: This is the unexpected blockage of an anticipated goal attainment within the organization, as measured with organizational frustration scale by Spector (1975). 
Global Journal of Human Resource Management

Vol.8, No.1, pp.1-19, February 2020

Published by ECRTD-UK

Print ISSN: 2053-5686(Print), Online ISSN: 2053-5694(Online)

\section{LITERATURE REVIEW}

The review was presented in two perspectives, namely theoretical review and empirical review.

\section{THEORETICAL REVIEW}

\section{On Job-Related Tension}

Cognitive-relational theory: It is the process through which people manage their environment to maintain an optimum level of physical, psychological and social well-being (Hart \& Cooper, 2001). According to the cognitive-relational approach, people's experience of their environment is constantly appraised. Appraisal is a cognitive process through which a female banker constantly monitors the conditions in her environment to determine whether the conditions are likely to have consequences for her well-being or not (Zaki, 2020). Perception of stimuli determines the female bankers' attitudes, coping systems, and general behaviours towards the stimuli.

\section{On Perceived Organizational Justice}

DPI (distributive- procedural- interactional) justice theory: Organizational justice refers to the role of fairness in organizations and is closely related to employees' perceptions of fair treatment in the organization (Cohen-Charash \& Spector, 2001). Organizational justice is generally categorized into three sub-dimensions of distributive justice, procedural justice, and interactional justice. Distributive justice concerns female bankers' gain from outcomes or resource allocation in an organization. Procedural justice originated from a legal dispute context (Thibaut \& Walker, 1975). According to procedural justice theory, the outcomes that individuals receive, as well as the fairness of the processes used to plan and implement a given decision, play an important role when individuals perceive justice. According to Leventhal et al. (1980), the following six procedural rules should be crucial in all allocation contexts: Procedures should (a) be consistent (consistency), (b) be without self-interest (bias suppression), (c) be based on accurate information (accuracy), (d) provide opportunities to correct the decision (open to correction), (e) consider the interests of all concerned parties (representativeness), and (f) follow moral and ethical standards (observe ethics). Interactional justice is associated with a female banker's perceptions of fairness regarding the interactions with a decision-maker who is responsible for the process of resources allocation (Bies \& Moag, 1986). According to the interactional justice theory, individuals evaluate the fairness of these interactions by the quality of interpersonal treatment (Greenberg, 1993). Also, individuals focus on how much respect and dignity (interpersonal justice) they are shown by the decision-maker and the explanations (informational justice) provided by the decision-maker regarding results from the system (Greenberg, 1993). 
Global Journal of Human Resource Management

Vol.8, No.1, pp.1-19, February 2020

Published by ECRTD-UK

Print ISSN: 2053-5686(Print), Online ISSN: 2053-5694(Online)

\section{On Organizational Frustration}

Reflective-impulsive theory: The RI was propounded by Strack and Deutsch (2004). The theory explains behaviour as a joint function of two interacting systems, namely an impulsive system and a reflective system. These systems operate according to different computations, but run in parallel and interact in the course of processing. Whereas the reflective system influences behavior via decisions based on facts and values, the impulsive system elicits behavior through associative links and motivational orientations (Strack \& Deutsch, 2004). Frustration is characterized by incompatibility of goals. Whereas in most situations the obstacle is immediately present in the situation, the goal is only represented in memory. Female bankers' appraisals of controllability and goal expectancy play a crucial role in perception of frustration.

\section{EMPIRICAL REVIEW}

\section{On Job-related Tension}

The study by Mahal (2012) investigated occupational stress in relation to job satisfaction among call centre operators. About 100 participants were sampled through convenience and random sampling methods from employees working in the call centre located in Chandigarh. Pearson product moment correlation and multiple regression statistics were used to test the data collected. The findings of the study showed that occupational stress effected employees in several ways and a major source of employee turnover in many organizations. A study by Khatibi, Asadi, and Hamidi, (2009) examined the relationship between job stress and organizational commitment in National Olympic and Paralympic Academy (NOPA) employees. Statistical population of this research included all employees (full time) of NOPA and statistical sample was equal to the statistical population $(\mathrm{n}=59)$. Job stress questionnaire (JSQ) and organizational commitment questionnaire were used to gather the data. The results indicated a negative significant relationship between job stress and organizational commitment, affective commitment and normative commitment, but there was not a significant relationship between job stress and continuance commitment. In Essiam, Mensah, Kudu, and Gyamfi (2015) there was a study to investigate the influence of role overload, role ambiguity, physical environment, supervisors support and coworkers support on job satisfaction among employees of a public university in Ghana. The researchers used a cross-sectional survey that adopted the convenience sampling technique to select 210 staff of the university. A questionnaire was used to gather the data. Findings indicated that role overload $(\beta=.17, \mathrm{p}<.05)$ and physical environment $(\beta=.13, \mathrm{p}<.05)$ contributed positive but small effect to the variance in the job satisfaction. Finding also revealed that there was a negative with no significant relationship between job satisfaction and co-workers support ( $\beta=-.01$, $\mathrm{p}=\mathrm{n} . \mathrm{s})$. Further finding indicated that the overall effect size of the stressors in the variance of job satisfaction was practically small $[\mathrm{R} 2 \leq .08, \mathrm{~F}(5,210)=4.51, \mathrm{p}=.001]$ and that the job stressors only explained $8 \%$ of the variance in job satisfaction. 
Global Journal of Human Resource Management

Vol.8, No.1, pp.1-19, February 2020

Published by ECRTD-UK

Print ISSN: 2053-5686(Print), Online ISSN: 2053-5694(Online)

\section{On Perceived Organizational Justice}

Study by Rahman, Haque, Elahi, and Miah (2015) examined the impact of the three facets of organizational justice on employee job satisfaction as perceived by the respondents in a particular pharmaceutical company in Bangladesh. A total of 76 executives working in the company provided their responses on the questionnaire used for data gathering. Descriptive statistics revealed the means of three variables of organizational justice and job satisfaction were close to 3.0. Reliability of measurement instrument was considered adequate, since all the Cronbach alpha values were found to be above the threshold point of .70. Multiple regression was applied to test the hypothesis of the study. The model explained about $75 \%$ of the variance in the employees' job satisfaction and it was immuned to multi-collinearity among the independent variables. The study findings demonstrated significant impact of distributive justice and interactional justice on job satisfaction at $\mathrm{P}<0.001$ and $\mathrm{P}<0.01$ respectively. Conversely, procedural justice did not show any significant relationship with the job satisfaction.

In a study by Oh (2013), the purpose was to explore the relationship between organizational justice and career satisfaction of employees in the public sector of South Korea. A total of 279 employees in six public organizations in South Korea participated in this research. Based on a convenience sampling approach, a self-administered survey was used to obtain these employees' perceptions. All four constructs (distributive justice, procedural justice, interactional justice, and career satisfaction) were based on multi-item scales. While distributive justice and procedural justice were found to be significant, interactional justice was found to be non-significant. In terms of standardized coefficients, procedural justice accounted for the variance in career satisfaction more than distributive justice did. The study by Phayoonpun and Norazuwa (2014) examined the relationship between the facets of organizational justice namely distributive justice and procedural justice on turnover intention. About 550 IT professionals were sampled and surveyed from the ICT industry in Thailand. Using both SPSS and AMOS packages, the collected data were analyzed using a multivariate technique. This study found a statistically significant relationship between distributive justice, procedural justice and employees' turnover intention through the mediating effect of job satisfaction of IT professionals in Thailand.

Akram and Yan Xin Feng (2016) carried out a study to explore the impact of organizational justice in the form of distributive, procedural, interactional, temporal and spatial justice on the innovative work behavior of the employees working in telecommunication sector of China. Data were collected from 235 employees and analyzed by using correlation and multiple regression analyses. The results of these analyses suggested that all forms of organizational justice have a strong and positive impact on the innovative work behavior of the Chinese employees. Spatial and temporal justice were found explaining highest variance in innovative work behavior of employees respectively. 
Global Journal of Human Resource Management

Vol.8, No.1, pp.1-19, February 2020

Published by ECRTD-UK

Print ISSN: 2053-5686(Print), Online ISSN: 2053-5694(Online)

\section{On Organizational Frustration}

Helminger (2014) carried out a study investigating causes and consequences of interns' frustration. The qualitative study relied on 181 internship reports and 10 in-depth interviews. The participants were students of the Department of Politics and Administration at the University of Konstanz (Germany). A combined analysis reveals that major triggers of internship frustration are insufficient supervision, unchallenging repetitive tasks as well as an adverse organizational culture. Subsequent consequences of interns' frustration were resignation and turnover intention, but also increased levels of learning. In contrast to employee frustration, it was shown that interns' reactions to frustration were more likely to be carried out mentally. Therefore, acts of violence and aggression were rare phenomena, due to incipiently lower levels of self-consciousness of the intern in the working world. The study by Gulzar, Yahya, Nauman, Mir, and Mujahid, (2012) focused on identifying the reactions, feelings and causes of frustration among university students of Pakistan. The sample of the study comprised of 120 individuals including boys $(\mathrm{n}=78)$ and girls $(n=42)$ from different universities of Lahore city. A questionnaire designed for data collection included close-ended questions. Reliability of Scale shows $\alpha=.85$. Chi-Square test was applied to verify demographics association with research questions. Result showed that greater academic demands from parents and losing or death of love ones are chief cause of frustration among students. Overall results about duration of frustration among university students had detected that most of the students faced frustration for less than one month. In a study to investigate effect of different stress stimulation on frustration tolerance of female college students with different temperament, Yao (2010) employed 145 female college students to perform four different training programs of aerobics, and then the frustration tolerance was investigated and analyzed. The results showed that frustration tolerance of female college students with phlegm temperament significantly increased with increasing stress stimulation $(\mathrm{p}<0.01)$. Frustration tolerance of female college students with choleric temperament, sanguine temperament and melancholic temperament varied with increasing stress stimulation, but the difference was not significant ( $\mathrm{p}>0.05$ ). Frustration tolerance of female college students with choleric temperament and sanguine temperament increased rapidly under high-intensity stress stimulation. Frustration tolerance of female college students with melancholic temperament showed U-shape under different levels of stress stimulation.

\section{Hypotheses}

1. Job-related tension will not predict organizational frustration among female bankers in Aguata suburban, Anambra State, Nigeria.

2. Perceived-organizational justice will not predict organizational frustration among female bankers in Aguata suburban, Anambra State, Nigeria.

\section{METHOD}

Participants: The participants for this study were 89 female bankers of seven commercial banks situated in Aguata suburban, Anambra State, Nigeria. Originally, 93 participants were selected, 
Global Journal of Human Resource Management

Vol.8, No.1, pp.1-19, February 2020

Published by ECRTD-UK

Print ISSN: 2053-5686(Print), Online ISSN: 2053-5694(Online)

but following the inability of 4 female bankers to attend to the instrument, only data collected from 89 participants were analyzed. Their age ranged from 26-56 years, with a mean age of 39.19 and a standard deviation of 7.35. They were sampled from First Bank Plc, Ekwulobia 16 (17.97\%); Access Bank Plc, Ekwulobia 14 (15.73\%); Zenith Bank Plc, Ekwulobia 13 (14.60\%); Eco Bank Plc, Ekwulobia 9 (10.11\%); First Continental Monument Bank (FCMB), Ekwulobia 15 (16.85\%); Union Bank, Uga 12 (13.48); and Union Bank, Igboukwu 10 (11.23\%), using cluster sampling and purposive sampling, in which 35 (39.33\%) was single while 54 (60.67\%) was married. All participants were female bankers, Christians, and Igbo by tribe.

Instruments: Three instruments used in this study included Job-related Tension Scale by Kahn, Wolfe, Quinn, Snoek, and Rosenthal (1964), Perceived-Organizational Justice Questionnaire (POJQ) by Niehoff and Moorman (1993), and Organizational Frustration Scale by Spector (1975).

Job-Related Tension Scale (JTS) was a 15-item inventory designed to measure job-related tension in the workplace (Kahn et al., 1964). Each item is responded to on a 5-point Likert scale pattern of 1 to 5 , where $1=$ Never, $2=$ Rarely, $3=$ Sometimes, $4=$ Rather Often, and $5=$ Nearly all the time. The items are scored directly. The current researchers did revalidations of the instruments, in which concurrent inter-instrument revalidations of the Job-Related Tension Scale with Organizational Frustration Scale had the Absolute Cosine of Vectors of Values as .96, with Lambda reliability coefficient of .85 .

The Perceived-Organizational Justice Questionnaire (POJQ) had 20-item measured on a 5point Likert type scale ranging from strongly disagree (1) to strongly agree (5). It was given divergent revalidation by the current researchers by correlating it with Organizational Frustration Scale. The dissimilarity matrix showed the Reversed Absolute Cosine of Vector of Values as -.95. The instrument also had parallel reliability coefficient of .71.

Organizational Frustration Scale (OFS) had 29 items measured on a 6-point Likert scale of $1=$ Disagree Completely, 2 = Disagree Pretty Much, 3 = Disagree Slightly, 4= Agree Slightly, 5 = Agree Pretty Much, and $6=$ Agree Completely. Spector (1975) reported a Cronbach alpha reliability coefficient of .88 and a construct validity coefficient of .59 by correlating OFS with the reactions to the construct "say something derogatory about your boss to other people". The current researchers concurrently revalidated the instruments with Job-Related Tension Scale, with the Absolute Cosine of Vectors of Values as .96, with the Lambda reliability coefficient as .80.

Procedure: A self-written introduction letter was given to each of the managers of the seven commercial banks used in this study to obtain their approval. The said banks included First Bank Plc, Ekwulobia, Access Bank Plc, Ekwulobia; Zenith Bank Plc, Ekwulobia; Eco Bank Plc, Ekwulobia; FCMB, Ekwulobia; Union Bank, Uga; and Union Bank, Igboukwu. The goal of the research was explained to the participants after establishing rapport with them. Two research assistants were co-opted and the research procedures were explained to them. Cluster sampling 
Global Journal of Human Resource Management

Vol.8, No.1, pp.1-19, February 2020

Published by ECRTD-UK

Print ISSN: 2053-5686(Print), Online ISSN: 2053-5694(Online)

was used to sample female bankers across the various cadres of the participants, while purposive sampling was used to sample participants of interest seen at the field of study that met the inclusion criteria and are willing to participate voluntarily in the study. The inclusion criteria for this study were: (1) the participant must be a female banker; (2) the participant must be an employee working in one of the selected commercial banks; and (3) the participant must show willingness on voluntary basis to participate in the study. Confidentiality and consent of the participants were strictly observed. The participants were equally guided on how to attend to the instruments truthfully. Immediately each of them finished attending to all the items on the instrument, it was collected for onward scoring and analysis.

Design/Statistic: This was a survey study that adopted cross-sectional predictive design. This was because the participants were studied in their usual place of endeavours. Again, job-related tension and perceived-organizational justice as the predictor independent variables (IVs) were examined on the organizational frustration as the dependent variables (DV). Descriptive statistics and multiple linear regression statistics were used to test the hypotheses postulated. Regression was used because of its power efficiency of converting the IVs into the DV and vice versa. Regression also has the power efficiency of determining the additive impacts of a variables, such as the respective impacts of job-related tension and perceived-organizational justice as the predictor independent variables (IVs) on organizational frustration as the dependent variables (DV).

\section{RESULTS}

The collected data were analyzed using the version 23 of the SPSS.

Table 1:

\begin{tabular}{|c|c|c|c|c|c|c|c|}
\hline & $\begin{array}{c}\mathrm{N} \\
\text { Statistic }\end{array}$ & $\begin{array}{l}\text { Range } \\
\text { Statistic }\end{array}$ & $\begin{array}{l}\text { Minimu } \\
\text { m } \\
\text { Statistic }\end{array}$ & $\begin{array}{c}\text { Maximum } \\
\text { Statistic }\end{array}$ & $\begin{array}{c}\text { Mean } \\
\text { Statistic }\end{array}$ & $\begin{array}{c}\text { Standard } \\
\text { Deviation } \\
\text { Statistic }\end{array}$ & $\begin{array}{l}\text { Variance } \\
\text { Statistic }\end{array}$ \\
\hline Age & 89 & 30.00 & 26.00 & 56.00 & 40.1236 & 8.49842 & 72.223 \\
\hline Religion & 89 & .00 & 1.00 & 1.00 & 1.0000 & .00000 & .000 \\
\hline Ethnicity & 89 & .00 & 1.00 & 1.00 & 1.0000 & .00000 & .000 \\
\hline Marital Status & 89 & 1.00 & 1.00 & 2.00 & 1.3933 & .49124 & .241 \\
\hline Job-Related Tension & 89 & 38.00 & 40.00 & 78.00 & 61.8090 & 6.91487 & 47.815 \\
\hline Perceived Organizational Justice & 89 & 58.00 & 40.00 & 98.00 & 78.8427 & 12.06978 & 145.680 \\
\hline Organizational Frustration & 89 & 131.00 & 36.00 & 167.00 & 92.9213 & 28.10420 & 789.846 \\
\hline Valid N (listwise) & 89 & & & & & & \\
\hline
\end{tabular}

Descriptive Statistics of Female Bankers in Aguata suburban, Anambra State, Nigeria

Source: Analysis of the researcher's primary data of Female Bankers in Aguata suburban, Anambra State, Nigeria 
The table showed the descriptive statistics of the participants. The means $(61.8090,78.8427$, and 92.9213 for the job-related tension, perceived-organizational justice, and organizational frustration variables respectively) varied so much. These reflected in the widening gap for the standard (Std) errors. Again, the high variations in the standard deviations and variance of the variables showed the participants' high degree of differences in their experiences for each variable of interest as well as the variables interaction impacts.

\section{Figure 1:}

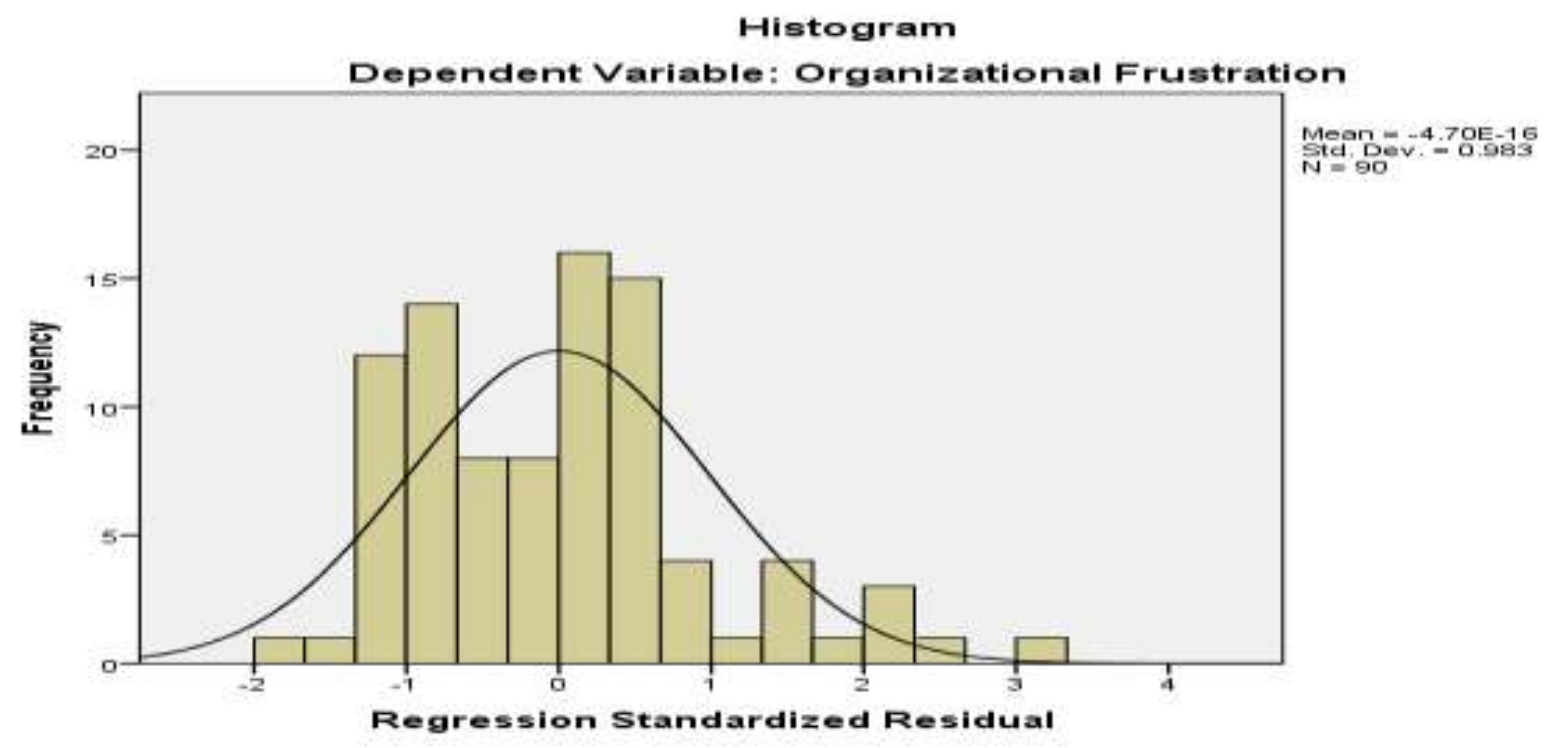

Histogram of Female Bankers in Aguata Suburban, Anambra State, Nigeria

Source: Analysis of the researcher's primary data of Female Bankers in Aguata suburban, Anambra State, Nigeria

The histogram graph (figure 1) showed the samples' performance for the tested variables for the mean (-4.70E-16) and standard deviation (0.983). The participants' performances were negatively skewed, with the strength of the standardized residual being stronger on negative side. The mean result was in the twilight zone/the outlier indicating that the participants had extreme (work) experiences of the tested variables. 


\section{Figure 2:}

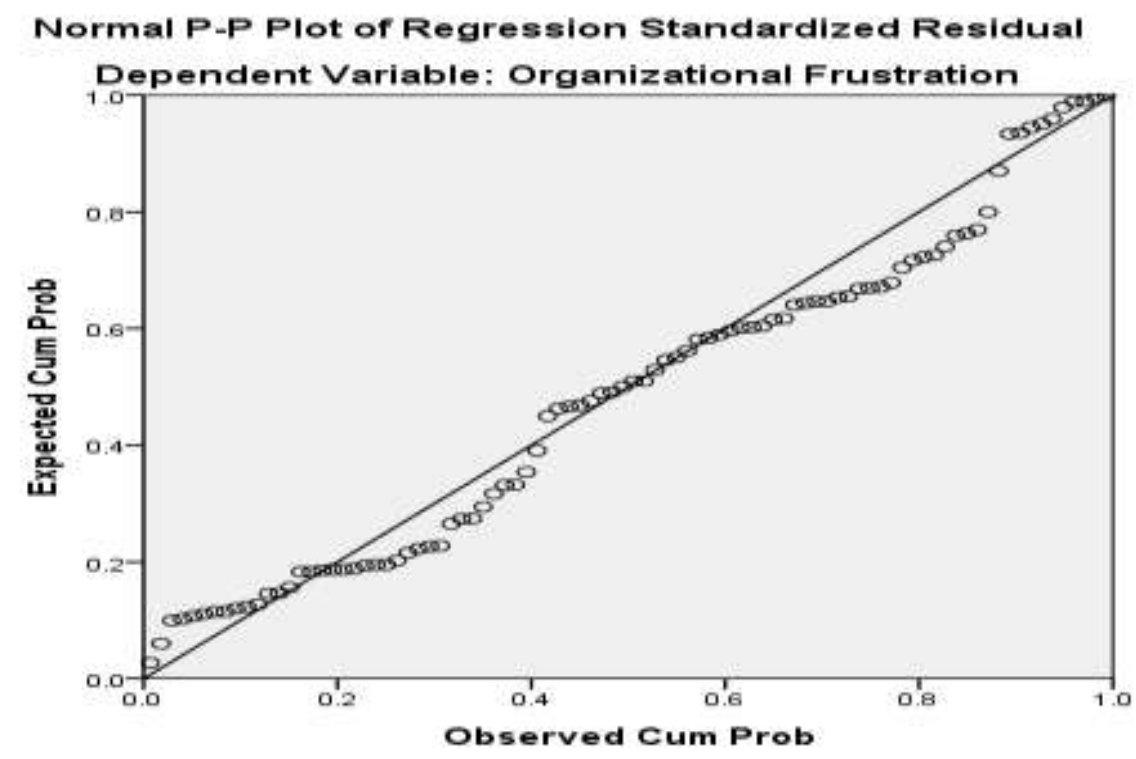

Histogram of Female Bankers in Aguata suburban, Anambra State, Nigeria

Source: Analysis of the researcher's primary data of Female Bankers in Aguata suburban, Anambra State, Nigeria

The standardized residual plot (figure 2) showed the samples' performance of female bankers in Aguata suburban, Anambra State, Nigeria. There was lack of fit in the plot. The scattergram was more on the observed probability (participants' work performance) than the expected probability (what the participants get from the bank in return).

\section{Table 2:}

\begin{tabular}{llrrr}
\multicolumn{4}{c}{ Correlations } & \\
& \multicolumn{1}{c}{$\mathbf{1}$} & $\mathbf{2}$ & $\mathbf{3}$ \\
\hline Pearson & 1. Organizational & 1.00 & & \\
Correlation & Frustration & 0 & & \\
& 2. Job-Related Tension & .223 & 1.000 & \\
& 3. Perceived & $*$ & & \\
& Organizational Justice & .143 & -.006 & \multirow{2}{*}{1.000} \\
\hline
\end{tabular}

Note: $N=89 ; * p<.05 ;$ Reject Ho@p @.05

Correlation Statistics of Female Bankers in Aguata suburban, Anambra State, Nigeria Source: Analysis of the researcher's primary data of female bankers in Aguata suburban, Anambra State, Nigeria. 
Global Journal of Human Resource Management

Vol.8, No.1, pp.1-19, February 2020

Published by ECRTD-UK

Print ISSN: 2053-5686(Print), Online ISSN: 2053-5694(Online)

The table 2 showed the samples' correlation experience for the variables tested. The results were significant for job-related tension and organizational frustration $(\mathrm{p}<.05, \mathrm{r}=.223, \mathrm{~N}=89)$ only; but not for perceived-organizational justice and organizational frustration $(\mathrm{p}<.05, \mathrm{r}=.143, \mathrm{~N} 89)$. Again, perceived-organizational justice had negative correlation with job-related tension $(\mathrm{p}<.05, \mathrm{r}$ $=-.006, \mathrm{~N}=89$ ).

Table 3:

\begin{tabular}{lll}
\hline Organizational Frustration & & \\
\hline Predictors & Step1 $\beta$ & Step2 \\
\hline Step1 - Job-Related Tension & $.223^{*}$ & .224 \\
& & $*$ \\
Step2 - Perceived Organizational & & \\
Justice & & .144 \\
\cline { 2 - 2 } $\boldsymbol{\Delta}$ & $4.573^{*}$ & 1.92 \\
$R^{2}$ & & 7 \\
$\Delta R^{2}$ & $.050^{*}$ & .071 \\
Df & $.050^{*}$ & .021 \\
& $1 ; 87$ & $1 ;$ \\
Durbin Watson & & 86 \\
\hline
\end{tabular}

Note: N=89; *p<.05; Reject Ho@p @.05

Result Regression Analyses Result of Female Bankers in Aguata Suburban, Anambra State, Nigeria

Source: Analysis of the researcher's primary data of Female Bankers in Aguata suburban, Anambra State, Nigeria

Table 3 showed the results of hierarchical multiple regression analyses for the hypotheses tested in the study. The overall model of the regression analyses was significant for job-related tension $\left(R^{2}=.050, \Delta R^{2}=.050, F(1,87)=4.573, p<.05\right)$, but not for perceived-organizational justice $\left(R^{2}\right.$ $\left.=.071, \Delta R^{2}=.021, F(1,86)=1.927, p<.05\right)$. Durbin Watson of $0<1.48<4$ showed positive errors autocorrelation. The overall fit of the model showed the final $71 \%$ accounting for the variations in sample. Job-related tension, which accounted for $50 \%$ variance, significantly predicted organizational frustration of female bankers $(\beta=.223 ; p<.05, N=90)$. When perceivedorganizational justice was added, it accounted for additional $21 \%$ variation without being a significant predictor of organizational frustration of the female bankers $(\beta=.224 ; p<.05, N=90)$. 
Global Journal of Human Resource Management

Vol.8, No.1, pp.1-19, February 2020

Published by ECRTD-UK

Print ISSN: 2053-5686(Print), Online ISSN: 2053-5694(Online)

\section{Summary of Results/Findings \\ Correlation}

1. Job-related tension had significant correlation with organizational frustration of Aguata suburban female bankers, Anambra State, Nigeria.

2. Perceived-organizational justice had no significant correlation with organizational frustration of female bankers.

3. Perceived-organizational justice had negative correlation with job-related tension of the female bankers.

\section{Prediction}

1. Job-related tension significantly predicted 50\% organizational frustration of Aguata suburban female bankers, Anambra State, Nigeria.

2. Perceived-organizational justice did not significantly predict organizational frustration of the female bankers and only $21 \%$ prediction was made.

\section{DISCUSSION}

One of the findings of the study is that job-related tension had significant correlation with organizational frustration of Aguata suburban female bankers, Anambra State, Nigeria. Consequently, job-related tension significantly predicted $50 \%$ organizational frustration of the female bankers. This related with the finding of Essiam, Mensah, Kudu, and Gyamfi (2015) that job tension affected behaviour negatively. Another finding of the study was that perceivedorganizational justice had no significant correlation with organizational frustration of the female bankers. As a result, perceived-organizational justice did not significantly predict organizational frustration of the female bankers, and only $21 \%$ prediction was made. The implication was that organizational justice played no significant role in moderating organizational frustration among the female bankers. This finding was contrary to that of Rahman, Haque, Elahi and Miah (2015) that organizational justice enhanced satisfaction in the workplace. Finally, it was also the finding of the study that perceived organizational justice had negative correlation with job-related tension of the female bankers. By implication, organizational justice moderated (lessened) job-related tension of Aguata sub-urban female bankers, Anambra State, Nigeria, which related with the earlier finding of Rahman, Haque, Elahi and Miah (2015). May it be noted that the study was limited to only Aguata suburban female bankers, Anambra State, Eastern Nigeria (Biafra), in which the male counterparts were excluded, with participants being predominantly Christians and Igbo by tribe. These could have some outcome and generalization implications for the study.

\section{Implications of the Study and its Findings}

The study and its findings have a number of knowledge-based and practical implications as itemized below.

1. Corruption and other unethical behaviours in the Nigerian banking system could be attributed to poor psychological health of the bankers. 
Global Journal of Human Resource Management

Vol.8, No.1, pp.1-19, February 2020

Published by ECRTD-UK

Print ISSN: 2053-5686(Print), Online ISSN: 2053-5694(Online)

2. Collapse of some banks in the Nigerian socio-economy could have been caused by human sabotage, frustration and tension associated with inability to meet target.

3. Bankers with poor psychological health will be detrimental to bank's performance and growth.

4. Psychological factor are the bedrock of human resources and organizational behaviour management.

5. Reducing psychological distress among female bankers could be a major panacea towards curbing feminine sociological challenge of sexual harassment.

6. Reducing psychological distress among female bankers will promoting their integration of work and family roles.

\section{CONCLUSION}

The study examined psychological distress of Aguata suburban female bankers, Anambra State, Nigeria. The interplay of job-related tension, organizational justice, and organizational frustration were investigated in the study. Job-related tension had significant correlation with organizational frustration of female bankers in Aguata suburban, Anambra State, Nigeria. Perceivedorganizational justice had no significant correlation with organizational frustration of the female bankers. Perceived-organizational justice had negative correlation with job-related tension of the female bankers. Job-related tension significantly predicted $50 \%$ organizational frustration of the female bankers in Aguata suburban, Anambra State, Nigeria. Perceived-organizational justice did not significantly predict organizational frustration of the female bankers and only $21 \%$ prediction was made.

\section{Recommendations}

From the findings of the study, the following recommendations are proffered:

1. Female bankers should develop the personal and professional strategies for handling/resolving psychological distress.

2. There is need to provide psychological intervention for female bankers manifesting psychological distress.

3. Organizational justice policies need to be complimented with proaction facilitators

\section{Suggestions for Further Studies}

1. Extended studies need to be conducted for the study by extending the sample size and scope of the study. This will enhance the generalizability of the findings.

2. Further studies need to incorporate both gender so as to provide a robust research and findings that will enrich knowledge.

3. There is need to replicate this study in other cultural backgrounds to see if the same findings might be obtained. This will also enhance the generalizability of the findings. 
Global Journal of Human Resource Management

Vol.8, No.1, pp.1-19, February 2020

Published by ECRTD-UK

Print ISSN: 2053-5686(Print), Online ISSN: 2053-5694(Online)

\section{REFERENCES}

Akram, T., \& Yan Xin Feng, M. (2016). The effects of organizational justice on the innovative work behavior of employees: An empirical study from China. Journal of Creativity and Business Innovation, 2, 114 -126.

Bies, R. J., \& Moag, J. S. (1986). Interactional justice: Communication criteria of fairness. Research on Negotiation in Organizations, 1, 43-55.

Cheeseborough, T., Overstreet, N. \& Ward, L. M. (2020). Interpersonal sexual objectification, jezebel stereotype endorsement, and justification of intimate partner violence toward women. Psychology of Women Quarterly, 6, January. https://doi.org/10.1177/0361684319896345

Cohen-Charash, Y., \& Spector, P. E. (2001). The role of justice in organizations: A meta- analysis. Organizational Behavior and Human Decision Processes, 86(2), 278-321.

Essiam , J. O., Mensah, M. E., Kudu, K. L., \& Gyamfi, G. D. (2015). Influence of job stress on job satisfaction among university staff: Analytical evidence from a public university in Ghana. International Journal of Economics, Commerce and Management, 3(2), 1-15.

Fawole, O. A. \& Isiaq, A. A. (2017). Job stress and marital quality among married women Bankers in Ilorin Metropolis. Bangladesh e-Journal of Sociology, 14(2), 104-110.

Greenberg, J. (1993). Stealing in the name of justice: Informational and interpersonal moderators of theft reactions to underpayment inequity. Organizational Behavior and Human Decision Processes, 54, 81-103.

Gulzar, S., Yahya, F., Nauman, M., Mir, Z., \& Mujahid, S. H. (2012). Frustration among University Students in Pakistan. International Research Journal of Social Sciences, 1(4), 7-15.

Hart, P.M. \& Cooper, C.L. (2001). Occupational stress: Toward a more integrated framework. In N. Anderson, D.S. Ones, H.K. Sinangil, \& C. Viswesvaran (Eds), Handbook of industrial, work and organizational psychology (vol 2, pp. 93-114). London: Sage.

Helminger, M. (2014). More than just coffee \& copying: A qualitative study of causes and consequences of interns' frustration. Master Thesis in Strategic HRM and Labour relations, Department of Sociology and Work Science, University of Gothenburg.

Hussain, H. \& Aslam, Q. (2015). Workplace bullying and employee performance among bank personnel in Pakistan. The Lahore Journal of Business, 3(2), 59-78.

Iyiola, A. R. (2011), Gender and racial differentials in the Nigerian banking industry. International Journal of Business and Management, 6(9), 228-233.

Kahn, R. L., Wolfe, D. M., Wuinn, R. P., Snoek, J. D., \& Rosenthal, R. (1964). Job-related tension: Studies in role conflict and ambiguity. New York: Wiley.

Khatibi, A., Asadi, H., \& Hamidi, M. (2009). The relationship between job stress and organizational commitment in National Olympic and Paralympic Academy. World Journal of Sport Sciences, 2(4), 272-278.

Kunle, A. O., Shittu, A. K., \& Kolawole, A. J. (2013). Impact of job insecurity, role perception and self-efficacy on bankers' affective wellbeing. IOSR Journal of Humanities and Social Science (IOSR-JHSS), 16(1), 59-67. 
Global Journal of Human Resource Management

Vol.8, No.1, pp.1-19, February 2020

Published by ECRTD-UK

Print ISSN: 2053-5686(Print), Online ISSN: 2053-5694(Online)

Leventhal, G., Karuza, J., \& Fry, W. (1980). Beyond fairness: A theory of allocation preferences. Justice and Social Interaction, 3, 167-218.

Mahal, P. K. (2012). Occupational stress in relation to job satisfaction: An empirical study of call centre. Indian Journal of Commerce \& Management Studies, 3(1), 42-47.

Mukah, S.T. (2020). Financial statement fraud likelihood determinants in micro financial institutions in Cameroon.European Journal of Accounting, Auditing and Finance Research (EJAAFR), 8(1), 14-29.

Niehoff, B. P. \& Moorman, R. H. (1993). Justice as a mediator of the relationship between methods of monitoring and organizational citizenship behavior. Academy of Management Journal, 36, (5), 527-556.

Ogechukwu, A.D. (2013). The current ethical challenges in Nigerian commercial banking sector. Global Journal of Management and Business Research Finance, 13(10), 35-50.

Oh, J. R. (2013). The impact of organizational justice on career satisfaction of employees in the public sector of South Korea. Unpublished PhD Dissertation, Faculty of the Graduate School, University of Minnesota.

Pallipedia (2020). Psychological distress. Pallipedia: The Free Online Palliative Care Dictionary. Retrieved $15^{\text {th }}$ January, 2020. https://pallipedia.org/psychological-distress/

Phayoonpun, T., \& Norazuwa, M. (2014). Organizational justice and turnover intention: The mediation role of job satisfaction. IPBJ, 6 (2), 1-21.

Pina, A. \& T.A. Gannon (2010). An overview of the literature on antecedents, perceptions and behavioural consequences of sexual harassment. Journal of Sexual Aggression, 3, 1-24.

Rahman, M., Haque, M., Elahi, F, \& Miah, W. (2015). Impact of organizational justice on employee job satisfaction: An empirical investigation. American Journal of Business and Management, 4(4), 162-171.

Spector, P. E. (1975). Relationships of organizational frustration with reported behavioural reactions of employees. Journal of Applied Psychology, 60, 635 - 637.

Strack, F. \& Deutsch, R. (2004). Reflective and impulsive determinants of social behavior. Personality and Social Psychology Review, 8, 220-247.

Thibaut, J., \& Walker, L. (1978). A theory of procedure. California Law Review, 66, 541-566.

van den Bos, K. (2020). Unfairness and radicalization. Annual Review of Psychology, (71), 563588

Yao, L. (2010). Effect of different stress stimulation on frustration tolerance of female college students with different temperament. African Journal of Business Management, 4(13), 27902795.

Zaki, J. (2020). Integrating empathy and interpersonal emotion regulation. Annual Review of Psychology, 71, 517-540 
Global Journal of Human Resource Management

Vol.8, No.1, pp.1-19, February 2020

Published by ECRTD-UK

Print ISSN: 2053-5686(Print), Online ISSN: 2053-5694(Online)

\section{APPENDIX I \\ INSTRUMENTS FOR THE STUDY}

\section{JOB-RELATED TENSION SCALE}

\begin{tabular}{|c|c|c|c|c|c|c|}
\hline S/no & HOW BOTHERED ARE YOU ABOUT ... & $\begin{array}{l}\exists \\
\vdots \\
\bar{z} \\
z \\
z\end{array}$ & 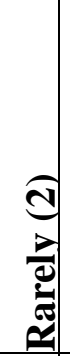 & 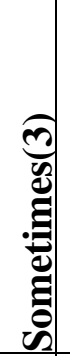 & 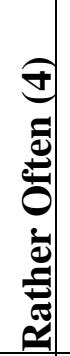 & 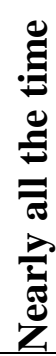 \\
\hline 1 & $\begin{array}{l}\text { Feeling that you have too little authority to carry out the } \\
\text { responsibilities assigned to you. }\end{array}$ & 1 & 2 & 3 & 4 & 5 \\
\hline 2 & $\begin{array}{l}\text { Being unclear on just what the scope and responsibilities of your job } \\
\text { are. }\end{array}$ & 1 & 2 & 3 & 4 & 5 \\
\hline 3 & $\begin{array}{l}\text { Not knowing what opportunities for advancement or promotion that } \\
\text { exist in the job. }\end{array}$ & 1 & 2 & 3 & 4 & 5 \\
\hline 4 & $\begin{array}{l}\text { Feeling that you have too heavy a workload, one that you can't } \\
\text { possibly finish during an ordinary workday. }\end{array}$ & 1 & 2 & 3 & 4 & 5 \\
\hline 5 & $\begin{array}{l}\text { Feeling that you will not be able to satisfy the conflicting demands } \\
\text { of various people over. }\end{array}$ & 1 & 2 & 3 & 4 & 5 \\
\hline 6 & Feeling that you are not fully qualified to handle your job. & 1 & 2 & 3 & 4 & 5 \\
\hline 7 & $\begin{array}{l}\text { Not knowing what your immediate supervisor thinks of you, how } \\
\text { s/he evaluates your performance. }\end{array}$ & 1 & 2 & 3 & 4 & 5 \\
\hline 8 & The fact that you can't get information needed to carry out your job. & 1 & 2 & 3 & 4 & 5 \\
\hline 9 & $\begin{array}{l}\text { Having to decide the things that affect the lives of individuals and } \\
\text { people that you know. }\end{array}$ & 1 & 2 & 3 & 4 & 5 \\
\hline 10 & $\begin{array}{l}\text { Feeling that you may not be liked and accepted by people you work } \\
\text { with. }\end{array}$ & 1 & 2 & 3 & 4 & 5 \\
\hline 11 & $\begin{array}{l}\text { Feeling unable to influence your immediate supervisor's decisions } \\
\text { and actions that affect you. }\end{array}$ & 1 & 2 & 3 & 4 & 5 \\
\hline 12 & Not knowing just what the people you work with expects of you. & 1 & 2 & 3 & 4 & 5 \\
\hline 13 & $\begin{array}{l}\text { Thinking that the amount of work you have to do may interfere with } \\
\text { how well it gets done. }\end{array}$ & 1 & 2 & 3 & 4 & 5 \\
\hline 14 & $\begin{array}{l}\text { Feeling that you have to do things on the job that are against you } \\
\text { better judgment. }\end{array}$ & 1 & 2 & 3 & 4 & 5 \\
\hline 15 & Feeling that your job tends to interfere with your family life. & 1 & 2 & 3 & 4 & 5 \\
\hline
\end{tabular}

\section{Developed by Kahn, Wolfe, Quinn \& Snoek (1964)}


Global Journal of Human Resource Management

Vol.8, No.1, pp.1-19, February 2020

Published by ECRTD-UK

Print ISSN: 2053-5686(Print), Online ISSN: 2053-5694(Online)

\section{PERCEIVED-ORGANIZATIONAL JUSTICE QUESTIONNAIRE (POJQ)}

\begin{tabular}{|c|c|c|c|c|c|c|}
\hline $\begin{array}{l}\text { S/ } \\
\text { No } \\
.\end{array}$ & ITEMS & 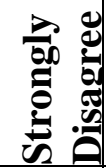 & 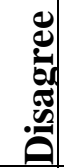 & $\begin{array}{l}\bar{\sigma} \\
\overrightarrow{3} \\
\bar{z} \\
z \\
z\end{array}$ & 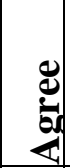 & 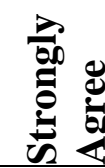 \\
\hline 1 & My work schedule is fair & 1 & 2 & 3 & 4 & 5 \\
\hline 2 & I think my level of pay is fair & 1 & 2 & 3 & 4 & 5 \\
\hline 3 & I consider my workload to be fair & 1 & 2 & 3 & 4 & 5 \\
\hline 4 & Overall, the rewards I receive here is quite fair & 1 & 2 & 3 & 4 & 5 \\
\hline 5 & I feel that my job responsibilities are fair & 1 & 2 & 3 & 4 & 5 \\
\hline 6 & Job decisions are made by my management in an unbiased manner & 1 & 2 & 3 & 4 & 5 \\
\hline 7 & $\begin{array}{l}\text { My management makes sure that all employee concerns are heard } \\
\text { before job decisions are made }\end{array}$ & 1 & 2 & 3 & 4 & 5 \\
\hline 8 & $\begin{array}{l}\text { To make job decisions, my management collects accurate and } \\
\text { complete information }\end{array}$ & 1 & 2 & 3 & 4 & 5 \\
\hline 9 & $\begin{array}{l}\text { My management clarifies decisions and provides additional } \\
\text { information when requested by employees }\end{array}$ & 1 & 2 & 3 & 4 & 5 \\
\hline 10 & $\begin{array}{l}\text { All jobs decisions are applied consistently across all affected } \\
\text { employees }\end{array}$ & 1 & 2 & 3 & 4 & 5 \\
\hline 11 & $\begin{array}{l}\text { Employees are allowed to challenge or appeal job decisions made } \\
\text { by management }\end{array}$ & 1 & 2 & 3 & 4 & 5 \\
\hline 12 & $\begin{array}{l}\text { When decisions are made about my job, management treats me with } \\
\text { kindness and consideration }\end{array}$ & 1 & 2 & 3 & 4 & 5 \\
\hline 13 & $\begin{array}{l}\text { When decisions are made about my job, management treats me with } \\
\text { respect and dignity }\end{array}$ & 1 & 2 & 3 & 4 & 5 \\
\hline 14 & $\begin{array}{l}\text { When decisions are made about my job, management is sensitive to } \\
\text { my personal needs }\end{array}$ & 1 & 2 & 3 & 4 & 5 \\
\hline 15 & $\begin{array}{l}\text { When decisions are made about my job, management deals with me } \\
\text { in a truthful manner }\end{array}$ & 1 & 2 & 3 & 4 & 5 \\
\hline 16 & $\begin{array}{l}\text { When decisions are made about my job, management shows } \\
\text { concern for my rights as an employee }\end{array}$ & 1 & 2 & 3 & 4 & 5 \\
\hline 17 & $\begin{array}{l}\text { Concerning decisions made about my job, management discusses } \\
\text { the implications of the decisions with me }\end{array}$ & 1 & 2 & 3 & 4 & 5 \\
\hline 18 & $\begin{array}{l}\text { Management offers adequate justification for decisions made about } \\
\text { my job }\end{array}$ & 1 & 2 & 3 & 4 & 5 \\
\hline 19 & $\begin{array}{l}\text { When making decisions about my job, management offers } \\
\text { explanations that make sense to me }\end{array}$ & 1 & 2 & 3 & 4 & 5 \\
\hline 20 & Management explains very clearly any decision made about my job & 1 & 2 & 3 & 4 & 5 \\
\hline
\end{tabular}

\section{Developed by Niehoff and Moorman (1993)}


Global Journal of Human Resource Management

Vol.8, No.1, pp.1-19, February 2020

Published by ECRTD-UK

Print ISSN: 2053-5686(Print), Online ISSN: 2053-5694(Online)

ORGANIZATIONAL FRUSTRATION SCALE

\begin{tabular}{|c|c|c|c|c|c|c|c|}
\hline S/no & ITEMS & 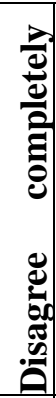 & 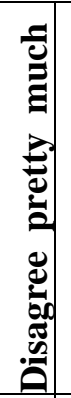 & 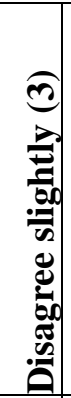 & 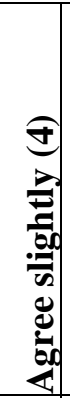 & $\begin{array}{l}0 \\
0 \\
0 \\
0 \\
\vdots \\
0 \\
0 \\
0 \\
0 \\
0 \\
0 \\
0 \\
0 \\
0 \\
0\end{array}$ & 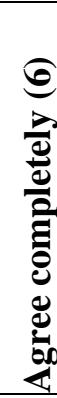 \\
\hline 1 & People act nasty towards me at work. & 1 & 2 & 3 & 4 & 5 & 6 \\
\hline 2 & I find that any time I try to do something at work I ran into obstacles. & 1 & 2 & 3 & 4 & 5 & 6 \\
\hline 3 & There are a lot of petty and arbitrary rules at work. & 1 & 2 & 3 & 4 & 5 & 6 \\
\hline 4 & I feel thwarted in my efforts to be creative. & 1 & 2 & 3 & 4 & 5 & 6 \\
\hline 5 & My supervisor is always chewing me out. & 1 & 2 & 3 & 4 & 5 & 6 \\
\hline 6 & My supervisor feels that my performance is worse than it is. & 1 & 2 & 3 & 4 & 5 & 6 \\
\hline 7 & I find it to talk to my supervisor. & 1 & 2 & 3 & 4 & 5 & 6 \\
\hline 8 & I feel that I am accomplishing something at work & 1 & 2 & 3 & 4 & 5 & 6 \\
\hline 9 & I enjoy my job. & 1 & 2 & 3 & 4 & 5 & 6 \\
\hline 10 & The demands made of me at work are reasonable. & 1 & 2 & 3 & 4 & 5 & 6 \\
\hline 11 & Policies at work are not fair. & 1 & 2 & 3 & 4 & 5 & 6 \\
\hline 12 & My work area is a pleasant place to be. & 1 & 2 & 3 & 4 & 5 & 6 \\
\hline 13 & I often feel that I am being run ragged. & 1 & 2 & 3 & 4 & 5 & 6 \\
\hline 14 & I am given entirely too much work to do. & 1 & 2 & 3 & 4 & 5 & 6 \\
\hline 15 & I find that some of the people I have to deal with are not competent. & 1 & 2 & 3 & 4 & 5 & 6 \\
\hline 16 & I often have problem doing my job because of incompetence of others. & 1 & 2 & 3 & 4 & 5 & 6 \\
\hline 17 & My supervisor always seems to be looking over my shoulder. & 1 & 2 & 3 & 4 & 5 & 6 \\
\hline 18 & My supervisor does not trust me. & 1 & 2 & 3 & 4 & 5 & 6 \\
\hline 19 & I feel trapped in my job. & 1 & 2 & 3 & 4 & 5 & 6 \\
\hline 20 & My job is not at fulfilling. & 1 & 2 & 3 & 4 & 5 & 6 \\
\hline 21 & I dread having to interact with my supervisor. & 1 & 2 & 3 & 4 & 5 & 6 \\
\hline 22 & I do not like many of the tasks that I have to do. & 1 & 2 & 3 & 4 & 5 & 6 \\
\hline 23 & My job is boring and monotonous. & 1 & 2 & 3 & 4 & 5 & 6 \\
\hline 24 & I get blamed for things that are not my fault. & 1 & 2 & 3 & 4 & 5 & 6 \\
\hline 25 & I don't have the authority to do what I am supposed to do at work. & 1 & 2 & 3 & 4 & 5 & 6 \\
\hline 26 & $\begin{array}{l}\text { It seems that one person tells me to do one thing and another person tell } \\
\text { me to do something else at work. }\end{array}$ & 1 & 2 & 3 & 4 & 5 & 6 \\
\hline 27 & I am told to do things I don't think I should do at work. & 1 & 2 & 3 & 4 & 5 & 6 \\
\hline 28 & I often have to waste time doing administrative tasks at work. & 1 & 2 & 3 & 4 & 5 & 6 \\
\hline 29 & I often feel frustrated at work. & 1 & 2 & 3 & 4 & 5 & 6 \\
\hline
\end{tabular}

Developed by P.E. Spector (1975). 